\title{
PENGARUH WAKTU HIGH ENERGY MILLING TERHADAP KARAKTERISTIK NANOKAOLIN CAPKALA ASAL KALIMANTAN BARAT
}

\author{
Muhamad Nasir", Popon Ratnasari**, Dwi Nur Fathan Islam **, Anis Shofiyani** \\ *Loka Penelitian Teknologi Bersih, Lembaga Ilmu Pengetahuan Indonesia, Komplek LIPI \\ Bandung. Jln. Sangkuriang. Gedung 50, Bandung \\ *** Jurusan Kimia, Fakultas MIPA, Universitas Tanjungpura, Jln. Prof. Dr. H. Hadari \\ Nawawi 78124, Pontianak \\ mnasir71@yahoo.com*'poponratnasari@student.untan.ac.id** \\ fathan.dni@student.untan.ac.id**,shofiyanianis9@gmail.com**
}

\begin{abstract}
Synthesis of nanokaolin from Capkala's natural clay from Bengkayang, West Borneo has been studied. Modification of kaolin particles into nano size was done by high energy milling methods using $\mathrm{HCl} 2 \mathrm{M}$ activator solutions. The variables that investigated is the effect of milling time on the particle size produced. Morphology and structure of nanokaolin were characterized using scanning electron microscope (SEM), x-ray diffraction (XRD) and fourier transform infrared spectrometer (FTIR). The result showed that the longer milling time produced smaller and uniform particles size of kaolin. The SEM result showed that kaolin has particle size about 64-158 $\mathrm{nm}$. The result of XRD showed that kaolin before and after milling has no different $2 \theta$ angle, but increased the peak intensity of mineral quartz. The result of IR spectra showed Al-O vibration on wavenumber $996,05 \mathrm{~cm}^{-}$ ${ }^{1}$ and $600,72 \mathrm{~cm}^{-1}$ and bending Si-O-Si vibration on wavenumber $666,77 \mathrm{~cm}^{-1}$.
\end{abstract}

Keywords : capkala's nanokaolin, morphology, structure, milling, high energy milling

\section{PENDAHULUAN}

Kaolin merupakan mineral clayjenis alumina-silikat dengan rumus molekul $\mathrm{Si}_{4} \mathrm{Al}_{4} \mathrm{O}_{10}(\mathrm{OH})_{8}$ dan komposisi $\mathrm{Al}_{2} \mathrm{O}_{3}: \mathrm{SiO}_{2}: \mathrm{H}_{2} \mathrm{O}$ adalah $1: 2: 2$ per sel satuan.yang memiliki struktur berlapis 1:1. Mineral kaolin ini merupakan lempung silikat dengan struktur berlapis, ukuran partikel $<2 \mathrm{~m}$, dan luas permukaan spesifik $7-20 \mathrm{~m}^{2} / \mathrm{g}$. Secara tradisional, kaolin banyak digunakanpada industri pembuatan kertas, cat, keramik, karet, plastik, cat, semen sebagai bahan pengisi, ingredient atau
extender(Kesuma, et al., 2013: Wahyuni et al., 2008). Bahan pengisi seperti kaolin berperan penting dalam memodifikasi sifat-sifat dari bahan polimer dengan cara meningkatkan sifat mekanik, elektrik, termal, dan optik (Anjanadan George, 2012).

Salah satu sumber kaolin yang melimpah adalah kaolin Capkala dari kabupaten Bengkayang, Kalimantan Barat. Dinas ESDM Kalimantan Barat tahun 2012 menyebutkan bahwa provinsi Kalimantan Barat memiliki kelimpahan kaolin sebanyak 316.908.857 ton dan 
E-ISSN : 2549-7464, P-ISSN : 1411-3724

tingkat eksploitasi mencapai 40.000 ton. Beberapa peneliti telah melaporkan pemanfaatan kaolin Capkala untuk berbagai tujuan sepertibahan baku adsorben (Kesuma, et al, 2013), untuk adsorpsi asam gibelerin (Sunardi, et al, 2009), dan sebagai bahan baku pembuatan aluminium sulfat (Jalaluddin dan Jamaluddin, 2005).

Beberapa peneliti juga telah melaporkan bahwa penggunaan pelarut asam dapat meningkatkan sifat mekanik dan porositas kaolin sehingga memiliki fungsi yang lebih bervariasi serta memiliki nilai ekonomis lebih tinggi.Sunardi et. al.(2009) melaporkan bahwa pencucian dengan pelarut asam kaolin bertujuan untuk mengurangi pengotor berupa mineral kuarsa, sedangkan Wahyuniet.al.(2008) melaporkan bahwa pelepasan logamlogam pengotor pada kaolin dengan perendaman menggunakan larutan $\mathrm{HCl}$ 6M memberikan hasil kapasitas adsorpsi dan luas permukaan kaolin. Namun belum ada yang secara khusus mensintesis atau memodifikasinya menjadi ukuran nanopartikel.

Berdasarkan pemikiran tersebut, penelitian ini bertujuan dan fokus untuk melakukan modifikasi kaolin Capkala menjadi nano-kaolin menggunakan metode high energy milling dan larutan $\mathrm{HCl}$ sebagai aktivator. Kemudian mempelajari mofologi dan struktur nanokaolin melalui analisis SEM, spektrofotometri FTIR, dan XRDModifikasi ukuran kaolin dalam skala nanometer diharapkan mampu meningkatkan sifat fisik dari kaolin seperti peningkatan luas permukaan spesifik.Tren pemanfaatan material maju yang mengarah pada nanomaterial memberikan sifat yang berbeda dalam hal ukuran partikel, luas permukaan dan sifat mekanik sehingga memberikan fungsi yang lebih aplikatif (Gun'ko, 2014; Kumar, 2015)..

\section{METODOLOGI PENELITIAN}

\section{Alat dan Bahan}

Alat-alat yang digunakan pada penelitian ini antara lain, ayakan 170 mesh, magnetic stirrer, seperangkat alat gelas, stirer, microscope optic fluoresence (MEIJI TECHNO AMERICA), neraca analitik (KERN \& Sohn Gmbh ABS 220-4), high energy milling (HEM-E3D), spektrofotometer FTIR (Thermo Scientific), sentrifus (BIOSAN LMC-3000), scanning electron microscope (SEM) HITACHI SU-3500), spektrofotometer ultrasonic waterbath (5510 BRANSON) dan $X$-ray diffraction $(X R D)$ (SHIMADZU EDX-720).

Bahan-bahan yang digunakan pada penelitian ini antara lain, akua d.m, asam klorida (HCl) (MERCK), dan kaolin Capkala.

\section{Cara Kerja \\ Preparasi kaolin Capkala}

Kaolin dicuci menggunakan akua d.m sebanyak3 kali, kemudian disentrifugasi dengan kecepatan 3000 rpm selama 5 menit.Kaolin hasil sentrifugasi dikeringkan pada suhu $70^{\circ} \mathrm{C}$ selama 12 jam.Kaolin yang telah kering kemudian diayak menggunakan ayakan 170 mesh.Sebanyak 50 gramkaolin dicuci menggunakan $\mathrm{HCl} 2 \mathrm{M}$ dengan perbandingan (1:10).Campuran diaduk selama 2 jam, kemudian filtrat didekantasi dan residu dinetralkan menggunakan akua d.m hingga $\mathrm{pH}$ netral.Setelah netral, kaolin dipisahkan dengan cara sentrifugasi pada kecepatan 3000 rpm selama 30 menit, dikeringkan dengan suhu $100^{\circ} \mathrm{C}$ selama 5 jam, diayak menggunakan ayakan 170 mesh dan 
E-ISSN : 2549-7464, P-ISSN : 1411-3724

ditimbang hingga berat konstan(Lindasari et.al., 2017).

\section{Sintesis Nanokaolin Capkala}

Sintesis nanokaolin dilakukan dengan metode top down menggunakan HEM Shaker Mill. Variasi waktu penggilingan yang digunakan adalah 6 , 12, dan 18 jam.Penggilingan dilakukan dengan memasukkan sampel kaolin teraktivasi $\mathrm{HCl} 2 \mathrm{M}$ kedalam alat milling.Rasio kaolin dan $\mathrm{HCl}$ yang digunakan yaitu 1:5.Proses milling dilakukan dengan kecepatan $745 \mathrm{rpm}$. Kaolin yang dihasilkan kemudian dikarakterisasi dengan analisis SEMEDAX, XRD, dan FTIR(Nugraha et.al., 2015).

\section{HASIL DAN PEMBAHASAN}

Kaolin yang digunakan diperoleh dari lempung Capkala Kabupaten Bengkayang Kalimantan Barat.Preparasi kaolin dilakukan melaui tahapan pencucian, pemisahan kuarsa dari lempung, pemanasan, penggerusan, dan pencucian menggunakan pelarut asam.Pencucian berulang bertujuan untuk memudahkan pemisahan kaolin dari mineral kuarsa.

Proses pemisahan kaolin dari kuarsa dilakukan dengan metode sentrifugasi. Metode ini dipilih didasarkan pada perbedaan ukuran dan berat jenis antara kuarsa dan kaolin.Perbedaan ukuran dan berat jenis antara kuarsa ( $\mathcal{~} \mathrm{m} ; 2,65 \mathrm{~g} / \mathrm{mL}$ ) dan kaolin ( $20 \mathrm{~m} ; \quad 2,60-2,63 \mathrm{~g} / \mathrm{mL})$ menyebabkan perbedaan kecepatan proses sedimentasi. Kuarsa yang memiliki ukuran dan berat jenis lebih besar akan terpisah pada lapisan bawah.Sedangkan proses pemanasan bertujuanuntuk menghilangkan kandungan air yang terperangkap pada struktur aluminosilikat kaolinyang dapat mengakibatkan kaolin mudah mengembang (Lindasari et.al., 2017).

Kaolinyang berhasil dipisahkan selanjutnya kembali dicuci menggunakanHCl $2 \mathrm{M}$ untuk melarutkan kotoran-kotoran berupa mineral logam serta untuk meningkatkan kuantitas pemisahan mineral kuarsadari kaolin (Lindasariet.al., 2017). $\mathrm{HCl} 2 \mathrm{M}$ merupakan konsentrasi optimum sebagai aktivator karena penggunaan konsentrasi yang terlalu rendah dapat mengakibatkan pengotor logam tidak dapat dibersihkan secara maksimal, sedangkan konsentrasi yang terlalu tinggi dikhawatirkan dapat mengakibatkan kerusakan kerangkan struktur aluminosilikat karena terjadinya dealuminasi pada kaolin akibat ion $\mathrm{H}^{+}$ yang terbentuk pada kondisi asam akan masuk ke dalam struktur aluminosilikat dan menggantikan posisi kation penyeimbang (Lindasari et.al., 2017). Sisa ion klorida dicuci dengan akua d.m secara berulang.

Kaolin yang dihasilkan kemudian diubah ukurannya secara fisika (top down) menggunakan HEM (High Energy Milling) Shaker Mill -E3D. Penggilingan dengan cara menggerus material dari bentuk meruah menjadi ukuran yang lebih kecil ini mengakibatkan suatu material mengalami pemecahan ukuran partikel (Nugraha et.al., 2015). Citra morfologi kaolin menggunakan mikroskop optik pada Tabel 1 menunjukkanbahwa waktu optimum untuk penggilingan adalah $12 \mathrm{jam}$. Hal ini didasarkan pada distribusi ukuran partikel kaolin yang lebih seragam (homogen) dibandingkan interval waktu-waktu yang lain. Morfologi SEM permukaan kaolin sebelum dan sesudah proses penggilingan ditunjukkan melalui Gambar 1. partikel kaolin sebelum proses penggilingan memiliki diameter kurang lebih $1 \mathrm{~m}$, 


\section{Eksakta Vol. 18 No. 2 Oktober 2017}

E-ISSN : 2549-7464, P-ISSN : 1411-3724

sedangkan kaolin sesudah proses penggilingan selama 12 jam memiliki diameter yang lebih kecil yakni antara158 $\mathrm{nm}$ dan $64 \mathrm{~nm}$. Berdasarkan morfologi yang ditunjukkan partikel-partikel cenderung membentuk aglomerat.Kompoisis unsur penyusun kaolin drai hasil EDAX pada Gambar 2memperlihatkanSi, Al, O, serta beberapa unsur-unsur lain dalam jumlah kecil seperti $\mathrm{Na}, \mathrm{K}, \mathrm{Ti}, \mathrm{C}, \mathrm{Mg}$, dan Fe. Kuantitas massa relatif masing-masing unsur untuknanokaolin adalah 13,20\%, $13.19 \%, 61.87 \%$, dan $11.74 \%$.

Hasil analisis FTIR ditunjukkan pada Gambar 3. pada spektra IR dari nanokaolin menunjukkan adanya pita serapan pada bilangan gelombang $3253,32 \mathrm{~cm}^{-1}$ dan $1632,93 \mathrm{~cm}^{-1}$ berturutturut menunjukkan adanya vibrasi ulur -
$\mathrm{OH}$ dan vibrasi tekuk -OH yang masih terperangkap pada kisi kristal (Sunardi et.al., 2011). Puncak serapan padabilangan gelombang $996,05 \mathrm{~cm}^{-1}$ dan $600,72 \mathrm{~cm}^{-1}$ menunjukkan vibrasi $\mathrm{Al}-\mathrm{O}$ yang merupakan serapan khas dari kaolin (Hosseini et.al., 2011). Puncak serapan pada bilangan gelombang $666,77 \mathrm{~cm}^{-}$ ${ }^{1}$ menunjukkan vibrasi tekuk Si-O-Si. Sedangkan serapan pada bilangan gelombang 1100, 1005, dan $1020 \mathrm{~cm}^{-}$ '(Wahyuni, 2010)yang menunjukkan adanya regangan $\mathrm{Si}-\mathrm{O}$ dan $\mathrm{Al}-\mathrm{O}$ tidak muncul pada spektra nanokaolin yang dihasilkan. Hal ini diasumsikan akibat proses penggilingan pada kaolin mengakibatkan putusnya ikatan Si-Odan Al-O pada kaolin. Sehingga ikatan Si-O dan Al-O pada nanokaolinhanya dalam jumlah yang sangat kecil. 


\section{Eksakta Vol. 18 No. 2 Oktober 2017}

E-ISSN : 2549-7464, P-ISSN : 1411-3724

Tabel 1. Morfologi partikel kaolin melalui proses Milling dengan variasi waktu Milling

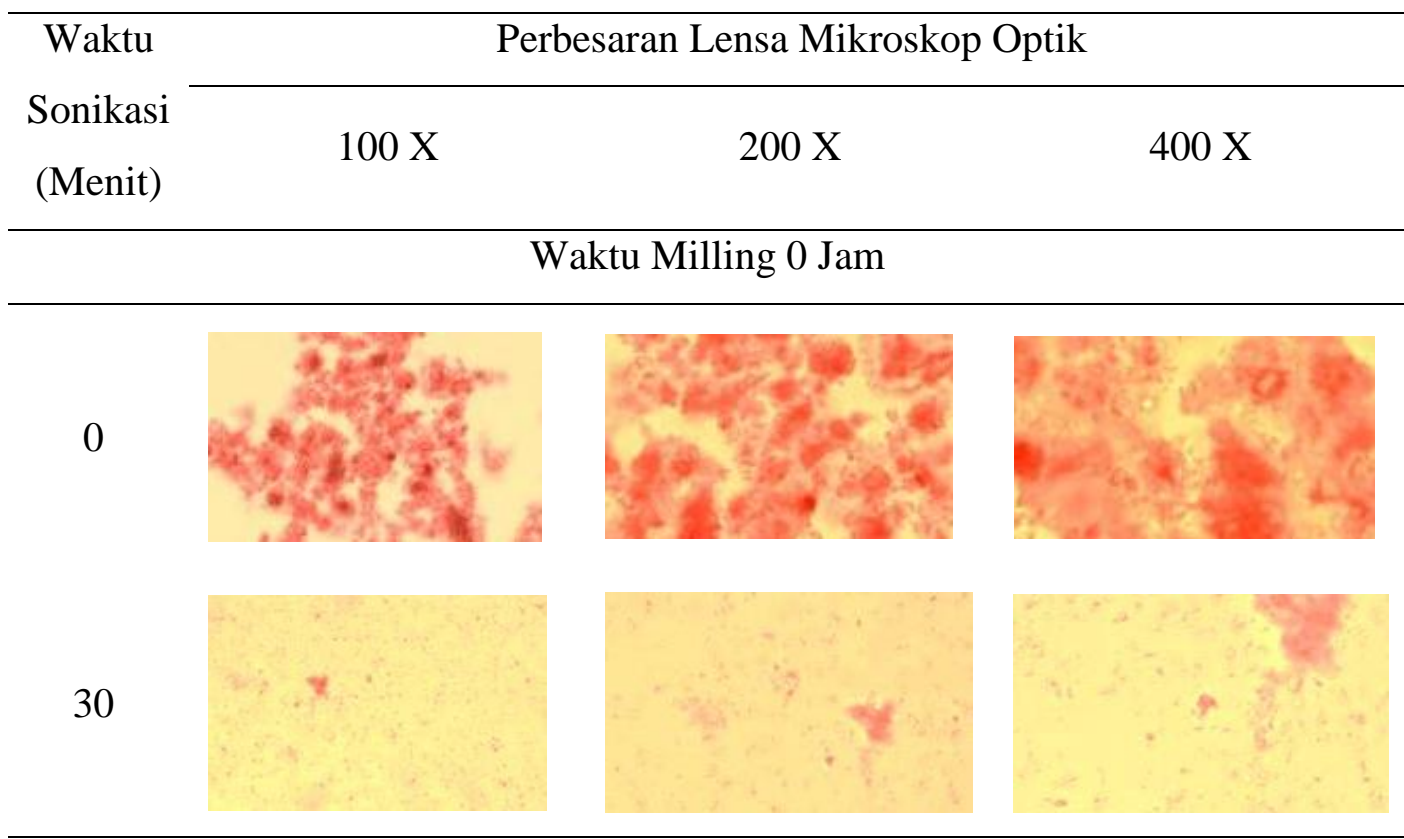

Waktu Milling 6 Jam

0
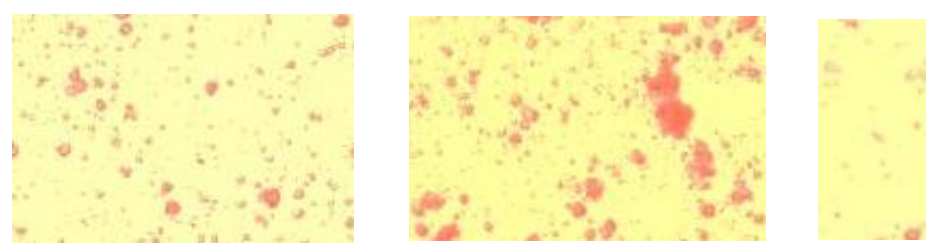

30
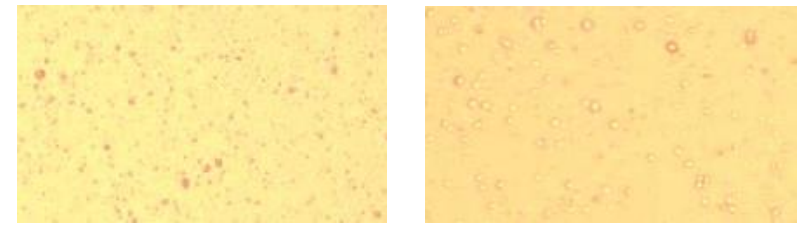

Waktu Milling 12 Jam

0
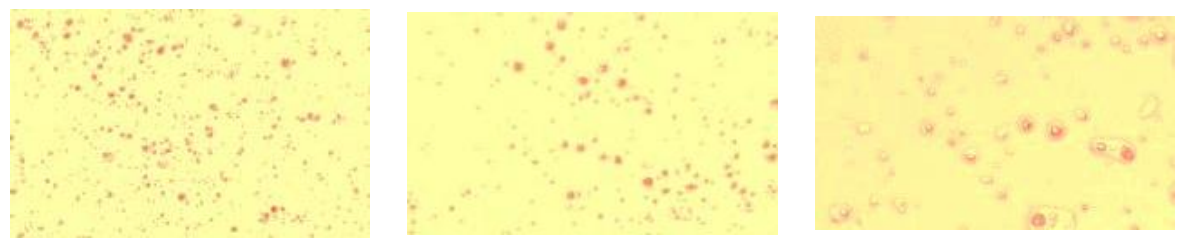


\section{Eksakta Vol. 18 No. 2 Oktober $\mid 2017$}

E-ISSN : 2549-7464, P-ISSN : 1411-3724

30

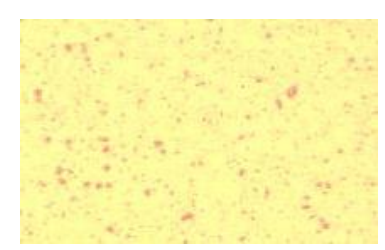

Waktu Milling 18 Jam

0

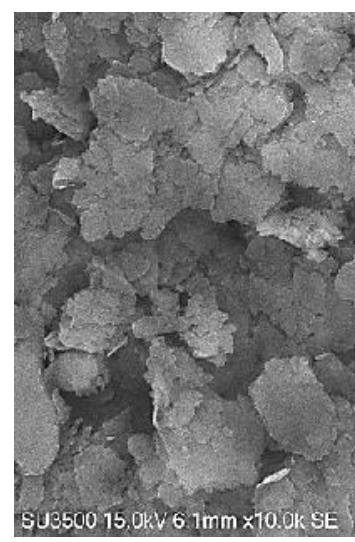

(a)

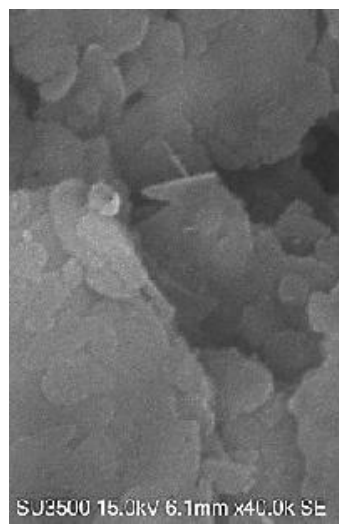

$\left(a^{*}\right)$
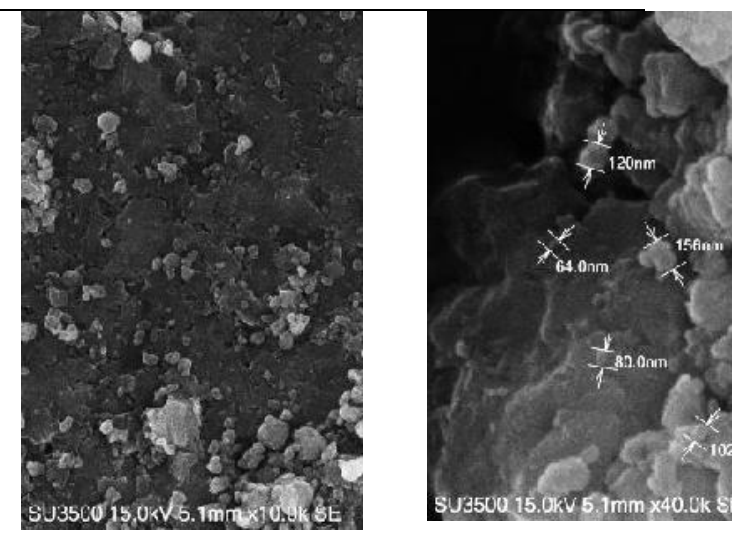

(b)

$\left(b^{*}\right)$

Gambar 1. Morfologi kaolin perbesaran 10.000X (a), 40.000X (a*) dan nanokaolin perbesaran $10.000 \mathrm{X}(\mathrm{b})$, 40.000X $\left(b^{*}\right)$ 
Eksakta Vol. 18 No. 2 Oktober $\mid 2017$

E-ISSN : 2549-7464, P-ISSN : 1411-3724

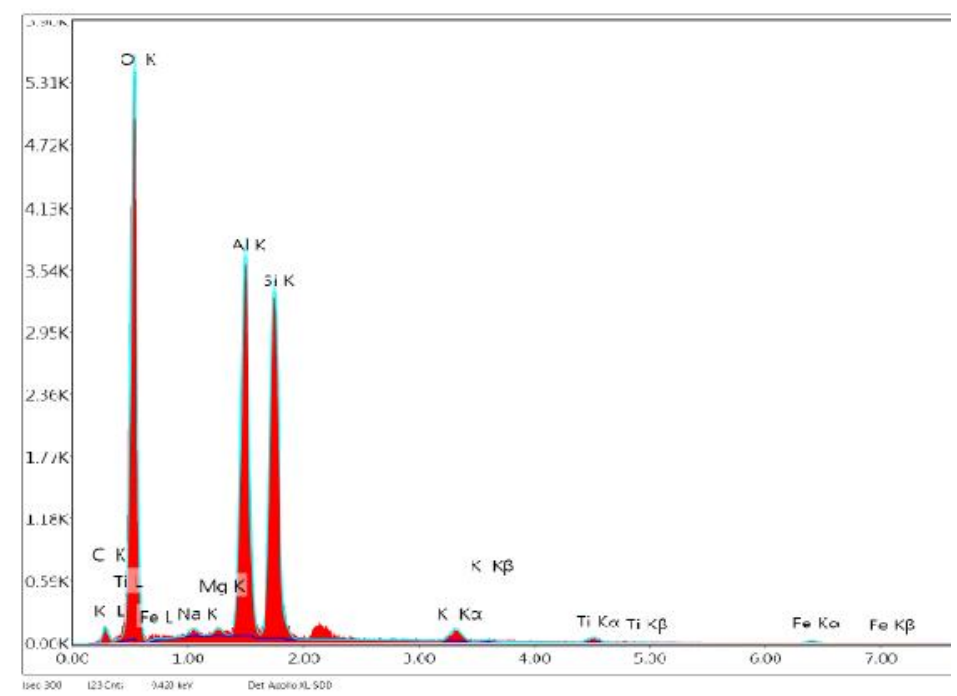

Gambar 2. Spektra EDAX dari

nanokaolin Capkala

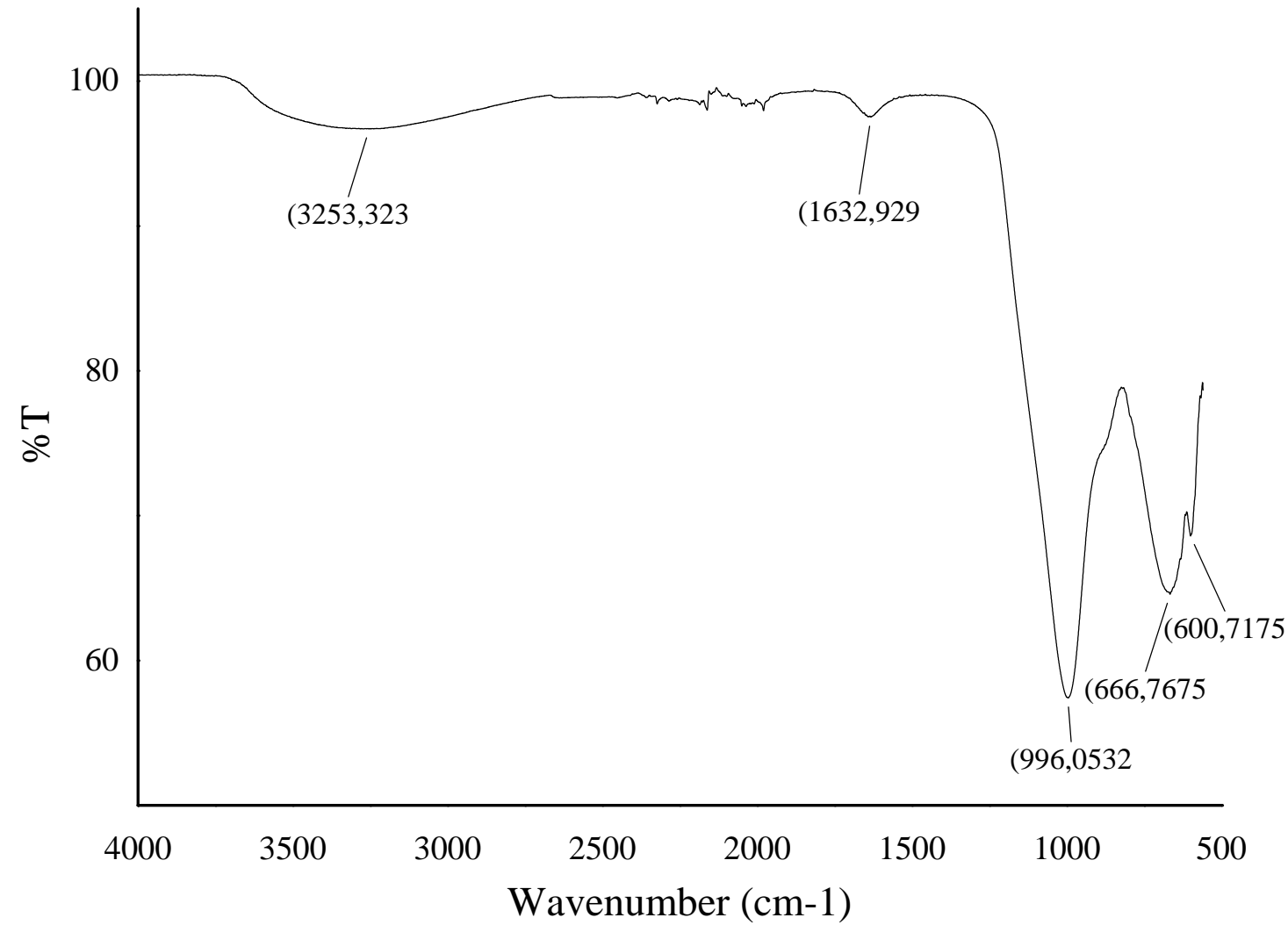

Gambar 3. Spektra IR nanokaolin

Capkala 
E-ISSN : 2549-7464, P-ISSN : 1411-3724

memiliki \% intensitas relatif berturutturut $73 \%$ dan $100 \%$. Sedangkan puncak

Tabel 2. Data $2 \theta$ dan d spacing dari

Kaolin dan Nanokaolin Capkala serapan dari nanokaolin ditunjukkan pada bidang $\mathrm{d}_{001}$ dengan sudut $2 \theta=12,1857^{\circ}(7,2574)$ dan bidang $\mathrm{d}_{002}$

Standar JCPDS Hasil Sintesis

\begin{tabular}{ccccc}
\multirow{2}{*}{ Sampel } & \multicolumn{2}{c}{ Standar JCPDS } & \multicolumn{2}{c}{ Hasil Sintesis } \\
\cline { 2 - 5 } Kaolin & $2 \theta$ & $\mathrm{d}$ spacing & $2 \theta$ & $\mathrm{d}$ spacing \\
& 12,4070 & 7,1283 & 12,5340 & 7,0565 \\
& 20,3771 & 4,3546 & 20,2421 & 4,3835 \\
& 24,9624 & 3,4641 & 25,1660 & 3,5359 \\
& 26,8832 & 3,3137 & 26,9152 & 3,3099 \\
Nanokaolin & 12,4070 & 7,1283 & 12,1857 & 7,2574 \\
& 20,3771 & 4,3546 & 20,0327 & 4,4288 \\
& 24,9624 & 3,4641 & 24,6717 & 3,6056 \\
& 26,8832 & 3,3137 & 26,8029 & 3,3235
\end{tabular}

Puncak-puncak difraksi kaolin dan nanokaolin hasil penelitian dibandingkan dengan standar pada JCPDS (Joint Committee on Powder Diffraction ) ditunjukkan melalui Tabel 2. Data hasil XRD juga menunjukkan adanya puncak karakrakteristik serapan pada bidang $\mathrm{d}_{001}$ dan $\mathrm{d}_{002}$ yang merupakan ciri dari kaolinit serta bidang $\mathrm{d}_{-110}$ dan $\mathrm{d}_{120 \text { yang }}$ merupakan ciri dari mineral kuarsa (Wahyuni et.al., 2008). Sesuai data JCPDS no 04-013-3074 (2017), hasil analisis XRD menunjukkan puncak karakteristik serapan dari kaolinit hasil preparasi pada bidang $\mathrm{d}_{001}$ dengan sudut $2 \theta=12,5340^{\circ}(7,0565)$ dan bidang $\mathrm{d}_{002}$ dengan sudut $2 \theta=25,1660^{\circ}(3,5359)$ yang dengan sudut $2 \theta=24,6717^{\mathrm{O}}(3,6056)$ yang Kfistalinitas \% intensitas relatif berturutturut $14 \%$ dan $46 \%$. Data analisis XRD 4j3,8åmerianjukkan puncak difraksi dari mineral kuarsa pada bidang $\mathrm{d}_{-110}$ dengan sudut $2 \theta=20,2421^{\mathrm{O}}(4,3835)$ dan bidang $\mathrm{d}_{120}$ dengan sudut $2 \theta=26,9152^{\mathrm{O}}(3,3099)$ yang memiliki \% intensitas relatif berturut-turut $99 \%$ dan 35\%. Sedangkan 31604 an hasil proses penggilingan menunjukkan perubahan intesitas puncak serapan pada bidang $\mathrm{d}_{-110}$ dengan sudut $2 \theta=20,0327^{\mathrm{O}}(4,4288)$ dan bidang $\mathrm{d}_{120}$ dengan sudut $2 \theta=26,8029^{\circ} \quad(3,3235)$ dengan $\%$ intensitas relatif berturut-turut $21 \%$ dan $100 \%$.

Hasil analisis XRD juga menunjukkan kristalinitas kaolin sebesar $43,8335 \%$ dan nanokaolin 35,6098\%. Adanya proses penggilingan mengakibatkan penurunan kristalinitas dari kaolin. Derajat kristalinitas suatu material menunjukkan kekuatan ikatan antar atom. Sehingga semakin tinggi derajat kristalinitas akan semakin kuat ikatan antar atom begitu juga sebaliknya (Saputri et.al., 2016). Pola difraktogram dari nanokaolin yang dihasilkan, memiliki kemirirpan dengan pola difraktogram metakaolin yang dikemukakan oleh Hosseini et.al. (2011). 

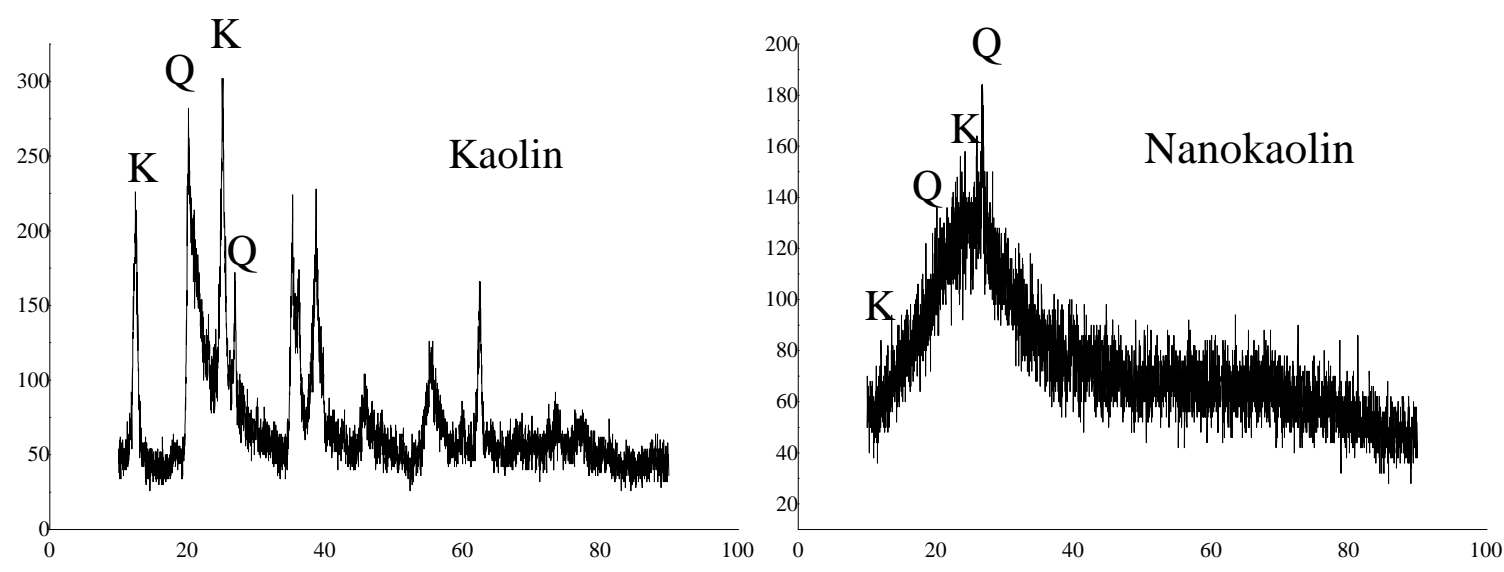

Gambar 4.Difraktogram kaolindan nanokaolin Capkala

\section{KESIMPULAN}

Berdasarkan hasil penelitian yang dilakukan dapat disimpulkan bahwa nanokaolin Capkala dapat disintesis dengan pendekatan top downmenggunakan metode penggilingan (high energy milling). Waktu yang optimum untuk proses penggilingan adalah12 jam dengan hasil ukuran partikel yang lebih seragam. Berdasarkan analisa hasil SEM nanokaolin mempunyai ukuran diameter 64-158 nm. Nanokaolin yang dihasilkan menunjukkan gugus fungsi Al-O dan $\mathrm{Si}-\mathrm{O}-\mathrm{Si}$ yang sesuai dengan gugus fungsi kaolin.

\section{DAFTAR PUSTAKA}

Anjana, R. dan George, K.E. 2012. Reinforcing Effect of Nano Kaolin Clay PP/HDPE Blends.Int. J. Eng. Res. and App. 2(4).

DinasEnergi dan Sumber Daya Mineral Provinsi Kalimantan Barat.2012.Kajian Kebijakan Pengembangan Industri Mineral Sebagai Kawasan Ekonomi Khusus.

Hosseini, S.A. Niaei, A. dan Salari, D. 2011. Production of $\gamma-\mathrm{Al} 2 \mathrm{O} 3$ from
Kaolin. Open. J.of Phy. Chem. 1(1): 24-25.

Gun'ko, Y. K. 2015. Magnetic Nanomaterial and Their Application. 4. 2079-4991: 505507.

Jalaluddin. dan Jamaluddin, T. 2005. Pemanfaatan Kaolin sebagai Bahan Baku Pembuatan Aluminium Sulfat dengan Metode Adsorpsi. J. Sistem Tek. Industri. 6(5): 71-73.

Kesuma, R.F.Sitorus, B. dan Adhitiyawarman. 2013. Karakterisasi Pori Adsorben Berbahan Baku Kaolin Capkala dan Zeolit Dealuminasi, J. Kim Khatulistiwa. 2303-1077: 19-23.

Kumar, L. Y. 2015. Role ang Adverse Effects of Nanomaterials in Food Technology. 2. 2056-3779: 1-3.

Lindasari, S. Rudiyansyah,dan Kiki, P. U.2017.Penentuan Kapasitas Adsorpsi Ion Clorida $\left(\mathrm{Cl}^{-}\right)$pada Pasir Kuarsa Terlapis Mangan Oksida dan Kaolin Teraktivasi HCl,J. Kim.Kha. 6(1): 12-13. 


\section{Eksakta Vol. 18 No. 2 Oktober $\mid 2017$}

E-ISSN : 2549-7464, P-ISSN : 1411-3724

Nugraha, P.R. Wahyu, W. Wahyu, T.C. dan Handoko, S.K. 2015. Pengaruh Aditif $\mathrm{BaCO}_{3}$ pda Kristalinitas dan Suseptibilitas Barium Ferit dengan Metode Metalurgi Serbuk Isotropik, J. Ber.Fis. 18(1): 42-43.

Saputri, L.H. Rochmadi. dan Budhijanto. 2016. Polyesterification of Shellac as An Alternative Coating Material.Pros. Sem Nas Tek Kim “Kejuangan”. 1693-4393.

Sunardi.Arryanto, Y. dan Sutarno, 2009.Adsorpsi Asam Giberelin pada Kaolin Asal Tatakan Kalimantan Selatan, J. Indo. Chem. 9(3): 373-379.

Sunardi. Irawati, U. dan Wianto, T. 2011. Karakterisasi Kaolin Lokal
Kalimantan Selatan Hasil

Kalsinasi.J. Fis FLUX, 8(1): 61-62.

Suyono, Y. 2012.Studi Awal Pembuatan Nanokomposit dengan FillerOrganoclayuntuk

Kemasan.Biopropal Industri. 3(2): 63-69.

Wahyuni, N. 2010. Modifikasi dengan Surfaktan Benzalkonium Klorida dan Karakterisasinya Menggunakan Spektrofotometer Infra Merah. J. Sains dan Ter Kim. 4(1): 4

Wahyuni, N, Imelda, H. S. Arryanto, Y. Sutarno dan Zupriadi, Y. 2008. Hidrolisis Lempung dari Kecamatan Capkala dengan Variasi Konsentrasi Larutan Asam Klorida.J. Zeolit Indonesia. 7(1): 1411-6723. 